\title{
ANALISIS POTENSI PENGEMBANGAN EKOWISATA PANTAI MANDEH KABUPATEN PESISIR SELATAN
}

\author{
Iswandi $\mathrm{U}$ \\ Jurusan Geografi Fakultas Ilmu Sosial Universitas Negeri Padang \\ iswandi_u@yahoo.com
}

\begin{abstract}
The tourism industry is the fault of the local revenue contributor, even foreign exchange earner of the country. Along with the tourist awareness of the environment and issues about sustainable development has contributed to the view of the importance of the principles of sustainable tourism. The principle of tourism is expected to maintain the quality of the environment, maintain the culture, empowering local communities and provide economic benefits to local communities, regions, and government. Mandeh beach is a tourist attraction that has a natural beauty, good food and friendly people. This study aimed to describe, analyze, and identify from ecotourism development based on internal factors and external factors. Internal factors include the development of ecotourism ecotourism development strengths and weaknesses. While external factors include the development of eco-tourism opportunities and threats. This study incorporates SWOT analysis method with AHP analysis. The analysis showed that the beach Mandeh have a positive potential for the development of ecotourism. Mandeh beach has a great opportunity and strength to be used as ecotourism.

Key words: Potential, development of ecotourism
\end{abstract}

\begin{abstract}
Abstrak
Industri pariwisata adalah kesalahan dari kontributor pendapatan daerah, bahkan luar negeri penghasil valuta negara. Seiring dengan kesadaran wisata lingkungan dan isu-isu tentang pembangunan berkelanjutan telah memberikan kontribusi terhadap pandangan pentingnya prinsipprinsip pariwisata berkelanjutan. Prinsip pariwisata diharapkan untuk menjaga kualitas lingkungan, mempertahankan budaya, pemberdayaan masyarakat lokal dan memberikan manfaat ekonomi kepada masyarakat lokal, daerah, dan pemerintah. Mandeh pantai merupakan objek wisata yang memiliki keindahan alam, makanan yang baik dan orang-orang yang ramah. Penelitian ini bertujuan untuk mendeskripsikan, menganalisis, dan mengidentifikasi dari pengembangan ekowisata berdasarkan faktor internal dan faktor eksternal. Faktor internal meliputi pengembangan kekuatan pengembangan ekowisata ekowisata dan kelemahan. Sedangkan faktor eksternal meliputi pengembangan peluang ekowisata dan ancaman. Penelitian ini menggabungkan metode analisis SWOT dengan analisis AHP. Hasil analisis menunjukkan bahwa pantai Mandeh memiliki potensi positif untuk pengembangan ekowisata. Mandeh pantai memiliki kesempatan besar dan kekuatan untuk digunakan sebagai ekowisata.
\end{abstract}

\section{PENDAHULUAN}

Perkembangan industri pariwisata tidak hanya terkait dengan bisnis perjalanan umum, tetapi juga pada tingkat kunjungan wisatawan pada kawasankawaasan yang dilindungi seperti taman nasional, cagar alam, dan yang lainnya. Seiring dengan kesadaran wisatawan terhadap lingkungan dan isu-isu tentang pembangunan berwawasan lingkungan telah memberikan kontribusi terhadap pandangan pentingnya prinsip-prinsip pariwisata yang berkelanjutan. Prinsip pariwisata ini diharapkan mampu mempertahankan kualitas lingkungan, 
mempertahankan budaya, memberdayakan masyarakat lokal dan memberikan manfaat ekonomi kepada masyarakat lokal, kawasan serta pemerintah (Fandeli et al. 2005).

Menurut Heriawan (1998) sektor pariwisata di percaya akan menjadi sektor potensial dalam pembangunan ekonomi masa depan yang berkaitan dengan persaingan global. Ada empat pusat perhatian dalam pengembangan sektor ini, yaitu (1) Perluasan dan obyek dan tujuan wisata dengan mempertimbangkan kekayaan alam dan beragam budaya bangsa, (2) Pengembangan berbagai fasilitas seperti hotel, restoran, transportasi termasuk program pengembangan sumberdaya manusia, (3) Peningkatan promosi dan pemasaran terutama pada negara-negara berpotensi serta pengembagan wisata potensial, (4) Perbaikan kualitas jasa pelayanan yang terkait dengan pariwisata dan (5) Karena bersifat multi dimensional maka diperlukan keterpaduan pembangunan lintas sektoral.

Menurut Gunn (1994) perencanaan pengembangan pariwisata ditentukan oleh keseimbangan potensi sumberdaya dan jasa yang dimiliki sebagai penawaran dan permintaan atau minat wisatawan sebagai permintaan. Komponen penawaran terdiri dari: a) atraksi (potensi keindahan alam dan budaya serta bentuk aktivitas wisata); b) transportasi (aksesibilitas); c) pelayanan informasi; dan d) akomodasi dan sebagainya.

Ekowisata pada saat sekarang ini menjadi aktivitas ekonomi yang penting yang memberikan kesempatan kepada wisatawan untuk mendapatkan pengalaman mengenai alam dan budaya untuk dipelajari dan memahami betapa pentingnya konservasi keanekaragaman hayati dan budaya lokal. Pada saat yang sama ekowisata dapat memberikan generating income untuk kegiatan konservasi dan keuntungan ekonomi pada masyarakat yang tingal di sekitar lokasi ekowisata (Fandeli dan Nurdin 2005).

Menurut Gunn (1994) bahwa kegiatan ekowisata biasanya berada didaerah tropis yang mempunyai keanekaragaman yang tinggi dan banyak flora dan fauna yang bersifat endemik sehingga kondisi tersebut rentan untuk mengalami perubahan. Dari sisi nilai tambah ekowisata, ada kemungkinan dalam implementasi program tersebut apabila tidak direncanakan dengan baik maka akan sebaliknya 
yang asalnya mendukung terhadap kelestarian lingkungan hidup malah menjadi mendorong terjadinya kerusakan lingkungan hidup di daerah tersebut. Oleh karena itu dalam pengembangan ekowisata perlu adanya rencana pengelolaan yang mengacu kepada tujuan utama awalnya yaitu mendorong dilakukannya pengawetan lingkungan hidup, sehingga ekowisata perlu di rencanakan pengelolaannya dengan mengintergrasikan dalam pendekatan sistem untuk konservasi yang menggunakan desain konservasi.

Industri pariwisata merupakan salah satu penyumbang pendapatan asli daerah (PAD). Namun banyak kegiatan industri pariwisata menyebabkan kerusakan lingkungan dan mengganggu ekosistem. Pantai Mandeh yang berlokasi di Kabupaten Pesisir Selatan merupakan pantai yang memiliki panarama dan keindahan alam pantai. Berdasarkan latar belakang diatas, maka yang menjadi pertanyaan penelitian bagaimanakah pengembangan ekowisata pantai Mandeh Kabupaten Pesisir Selatan.

Berdasarkan latar belakang dan rumusan masalah diatas maka penelitian ini memiliki tujuan untuk mendeskriptifkan, menganalisis, dan mengidentifikasi dari pengembangan ekowisata berdasarkan faktor internal dan faktor ekternal. Faktor internal pengembangan ekowisata meliputi kekuatan dan kelemahan pengembangan ekowisata. Sedangkan faktor eksternal pengembangan ekowisata meliputi peluang dan ancaman.

\section{METODOLOGI}

Penitian ini termasuk penelitian deskriptif dan menggunakan metode gabungan SWOT dengan AHP. Penelitian ini menganalisis potensi pengembangan ekowisata Pantai Mandeh Kabupaten Pesisir Selatan. Faktor ekternal (EFE dan faktor internal (IFE) pengembangan ekowisata dianalisis dengan menggukanakan AHP.

Analisis SWOT dan AHP pengembangan ekowisata pantai Mandeh dilakukan dengan beberapa tahapan antara lain: 
1. Menyusun faktor internal (IFE) dan faktor eksternal (EFE) dalam pengembangan ekowisata maka masing-masing faktor ditentukan bobot dan rangkingnya.

2. Pemberian bobot masing-masing faktor mulai dari sangat penting (1.0) sampai dengan tidak penting $(0,0)$.

3. Setelah bobot ditentukan kemudian rating ditentukan dari pengaruh. Nilai Rating memiliki rentang $1 \mathrm{~s} / \mathrm{d} 5$. Rating 1 berati tidak berpengaruh sedangkan rating 5 berati sangat berpengaruh.

4. Skor ditentukan hasil pengalian antara bobot dengan rating.

5. Kemudian tentukan total skor faktor internal dan faktor eksternal

\section{PEMBAHASAN}

Pengembangan ekowisata pantai Mandeh Kabupaten Pesisir Selatan dianalisis dengan metode SWOT meliputi kekuatan, kelemahan, peluang, dan ancaman diporoleh hasil sebagai berikut:

1. Kekuatan

a) Lokasi yang strategis

b) Objek wisata yang menarik

c) Masyarakat yang ramah dan terbuka

d) Sosial dan budaya yang menarik

e) Memiliki kekentalan budaya melayu

2. Kelemahan
a) Aksesbilitas
b) Sarana dan prasarana penunjang (hetel, jalan, restoran, kuliner)
c) Atraksi budaya yang kurang
d) Informasi, Komunikasi, Promosi yang lemah

3. Peluang
a) Meningkatkan PAD Kabupaten Pesisir Selatan
b) Mengerakan sektor perekonomian masyarakat.
c) Terangkatnya nilai-nilai budaya melayu yang sudah mulai terkikis budaya asing.
d) Munculnya kuliner asli masyarakat melayu. 
e) Tumbuh dan berkembangnya industri kepariwisataan.

\section{Ancaman}

a) Pengembangan Ekowisata dapat merusak kelestarian lingkungan

b) Terkikisnya nilia-nilai budaya melayu karena masuknya budaya asing

c) Hilangnya kuliner asli karena masuknya makanan asing

Faktor Internal dan Faktor Eksternal dalam pengembangan ekowisata pantai Mandeh dianalisis dengan menggunakan AHP. Hasil analisis AHP terhadap faktor eksternal dan internal dapat dilihat pada Gambar 1.
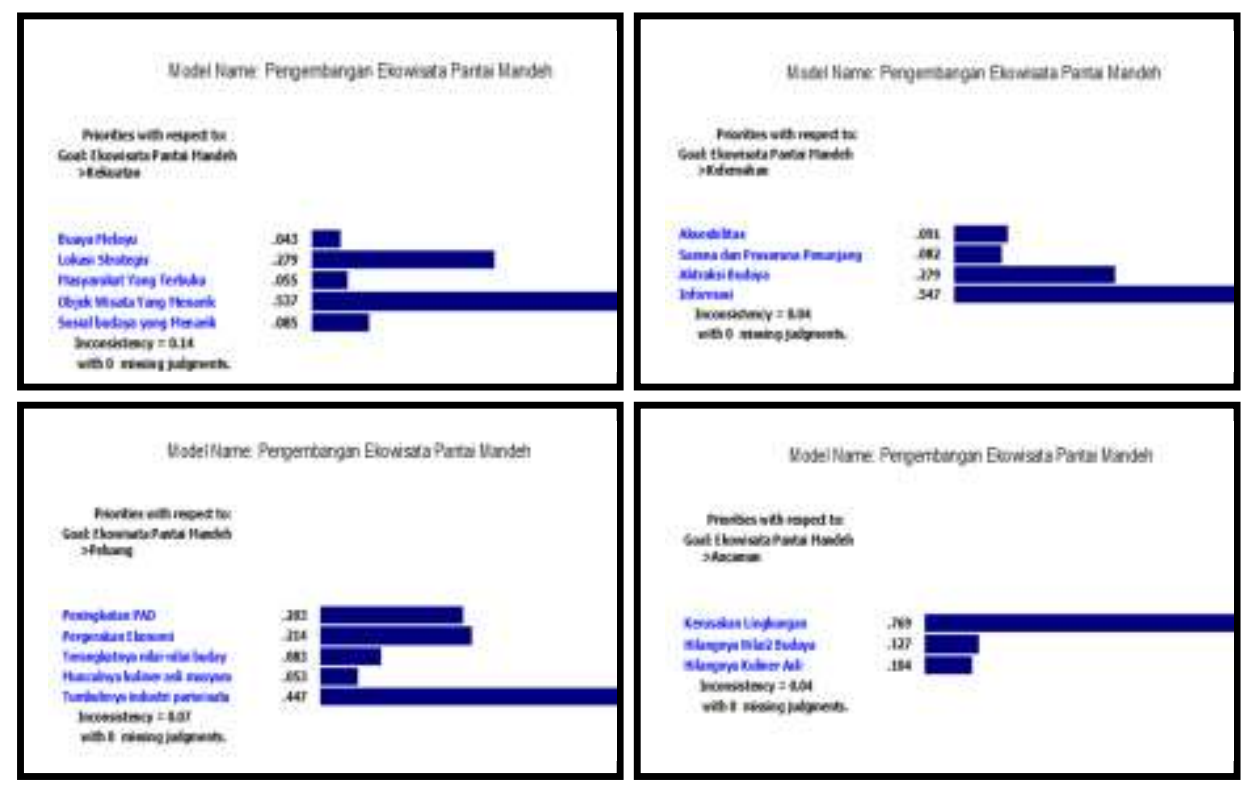

Hasil analisis AHP akan menentukan bobot, sedangkan rating didasarkan pada tingkat pengaruh dari masing-masing faktor terhadap pengembangan ekowisata pantai Mandeh. Untuk menentukan skor diperoleh dari pengalian bobot dengan rating. Hasil analisis bobot, rating, dan skor dapat dilihat pada Tabel 1.

\section{Tabel 1.}

\section{Hasil Analisis Pengembangan Ekowisata Pantai Mandeh}

\begin{tabular}{|c|c|c|c|}
\hline Faktor Pengembang Ekowisata & Bobot & Rating & Skor \\
\hline \multicolumn{4}{|l|}{ Faktor Internal (IFE) } \\
\hline 1. Kekuatan & & & \\
\hline a. Lokasi yang strategis & 0.279 & 5 & 1.395 \\
\hline b. Objek wisata yang menarik & 0.537 & 5 & 2.685 \\
\hline c. Masyarakat yang ramah dan terbuka & 0.055 & 3 & 0.165 \\
\hline d. Sosial dan budaya yang menarik & 0.065 & 4 & 0.260 \\
\hline e. Memiliki kekentalan budaya melayu & 0.043 & 4 & 0.172 \\
\hline
\end{tabular}




\begin{tabular}{|c|c|c|c|}
\hline Faktor Pengembang Ekowisata & Bobot & Rating & Skor \\
\hline & & & 4.677 \\
\hline $\begin{array}{l}\text { 2. Kelemahan } \\
\text { a. Aksesbilitas } \\
\text { b. Sarana dan prasarana penunjang (hetel, jalan, } \\
\text { restoran, kuliner) } \\
\text { c. Atraksi budaya yang kurang } \\
\text { d. Informasi, Komunikasi, Promosi yang lemah }\end{array}$ & $\begin{array}{l}0.279 \\
0.547\end{array}$ & $\begin{array}{l}3 \\
3\end{array}$ & $\begin{array}{l}0.837 \\
1.641 \\
3.070 \\
\end{array}$ \\
\hline Total Skor IFE & & & 1.607 \\
\hline Faktor Eksternal (EFE) & & & \\
\hline $\begin{array}{l}\text { 1. Peluang } \\
\text { a. Meningkatkan PAD Kabupaten Pesisir Selatan } \\
\text { b. Mengerakan sektor perekonomian } \\
\text { masyarakat. } \\
\text { c. Terangkatnya nilai-nilai budaya melayu yang } \\
\text { sudah mulai terkikis budaya asing. } \\
\text { d. Munculnya kuliner asli masyarakat melayu. } \\
\text { e. Tumbuh dan berkembangnya industri } \\
\text { kepariwisataan. }\end{array}$ & $\begin{array}{l}0.203 \\
0.214 \\
0.083 \\
0.053 \\
0.447\end{array}$ & $\begin{array}{l}4 \\
5\end{array}$ & $\begin{array}{l}0.812 \\
1.070 \\
0.332 \\
0.265 \\
1.788 \\
4.267\end{array}$ \\
\hline $\begin{array}{l}\text { 2. Ancaman } \\
\text { a. Pengembangan Ekowisata dapat merusak } \\
\text { kelestarian lingkungan } \\
\text { b. Terkikisnya nilia-nilai budaya melayu karena } \\
\text { masuknya budaya asing } \\
\text { c. Hilangnya kuliner asli karena masuknya } \\
\text { makanan asing }\end{array}$ & $\begin{array}{l}0.769 \\
0.127\end{array}$ & $\begin{array}{l}2 \\
2\end{array}$ & $\begin{array}{l}0.254 \\
0.104 \\
1.896\end{array}$ \\
\hline Total Skor EFE & & & 2.371 \\
\hline
\end{tabular}

Hasil analisis pengembangan ekowisata dengan menggunakan metode SWOT dan AHP menunjukkan bahwa faktor internal (IFE) dan faktor eksternal (EFE) bernilai positif. Selain itu, faktor eksternal lebih tinggi dibandingkan dengan faktor internal. Artinya bahwa pengembangan ekowisata pantai Mandeh Kabupaten Pesisir Selatan memiliki kekuatan dan peluang untuk dikembangkan. Hubungan antara faktor internal dan faktor eksternal dapat dilihat pada Gambar 2 di bawah. 


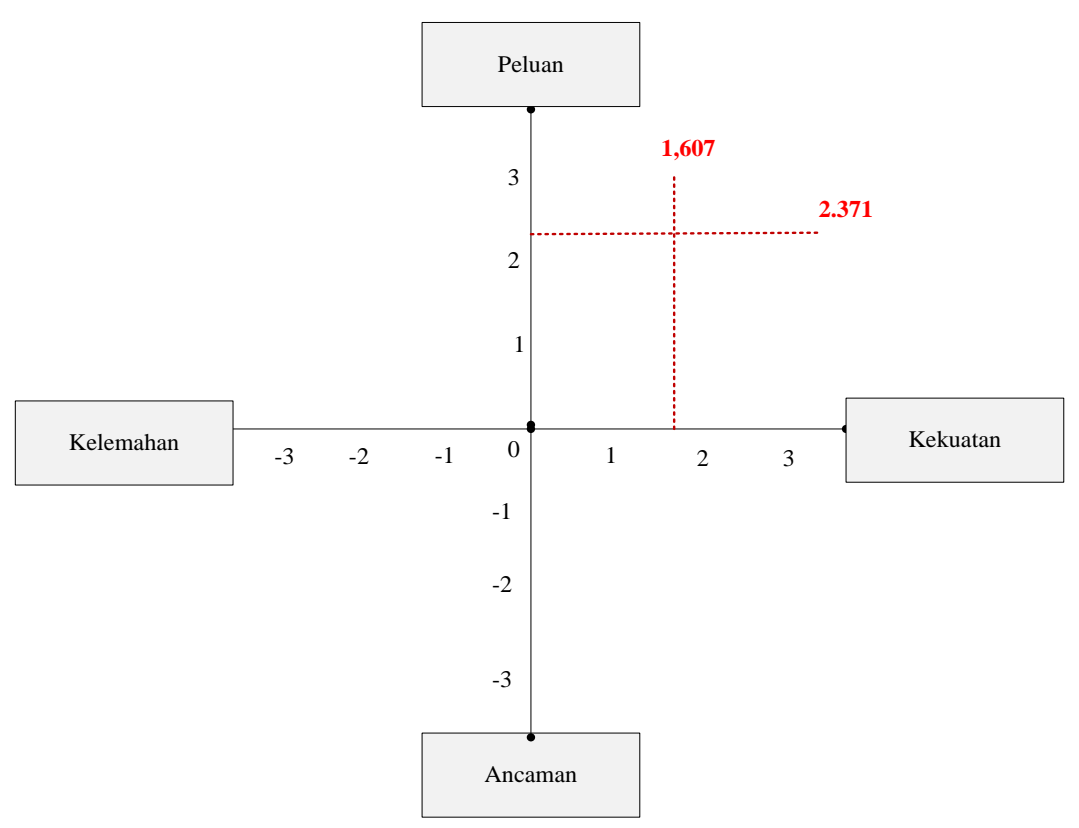

Upaya pencapaian keberhasilan dalam pengembangan ekowisata pantai Mandeh Kabupaten Pesisir Selatan dapat dilakukan secara optimal dengan meningkatkan faktor kekuatan dan memperbaiki faktor kelemahan menjadi energi positif. Selain itu, ancaman yang datang dari luar harus diantisipasi dengan meningkatkan kecintaan terhadap budaya dan kuliner lokal. Kerusakan lingkungan harus dibuat regulasi yang jelas terhadap pelaku industri kepariwisataan.

\section{KESIMPULAN}

Berdasarkan analisis dapat disimpulkan bahwa pengmbangan ekowisata pantai Mandeh Kabupaten Pesisir Selatan bernilai positif untuk dikembangkan. Faktor Eksternal memiliki nilai lebih tinggi dibandingkan faktor internal. Untuk pengembangan ekowisata pantai Mandeh Kabupaten Pesisir Selatan disarankan kepada Pemda khususnya Dinas Pariwisata untuk membuat aturan yang jelas dengan industri kepariwisataan untuk menjaga lingkungan pantai Mandeh, sehingga pengelolaan ekowisata berkelanjutan dapat terujut.

\section{DAFTAR PUSTAKA}

Eriyatno. 2012. Ilmu Sistem Meningkatkan Mutu dan Efektifitas Manajemen. Jilid Satu Edisi Keempat. Surabaya (ID): Guna Widya.

Eriyatno dan Larasati L. 2013. Ilmu Sistem. Meningkatkan Integrasi dan Koordinasi Manajemen. Jilid Dua. Edisi Pertama. Surabaya (ID): Guna Widya. 
Fandeli, D. 2000. Pengertian dan Konsep Dasar Ekowisata. Fakultas Kehutanan Universitas Gajah Mada. Yogyakarta.

Fandeli C dan Nurdin M. 2005. Pengembangan Ekowisata Berbasis Konservasi di Taman Nasional. Fakultas Kehutanan Universitas Gajah Mada. Yogyakarta.

Gunn CA. 1994. Tourism Planning: Basics, Concepts, Cases. Third Edition. London: Taylor and Francis Ltd.Washington DC.

Gold, S.M. 1980. Recreation Planning and Design. Mac Graw Hill Book Company. New York.

Marimin. 2004. Teknik dan Aplikasi Pengambilan Keputusan Kriteria Majemuk. Jakarta (ID): Grasindo. PT. Gramedia Widiasarana Indonesia.

Marimin dan Maghfiroh N. 2013. Aplikasi Teknik Pengambilan Keputusan dalam Manajemen Rantai Pasak. IPB Press

Pemerintah Republik Indonesia. 2009. Undang-Undang Republik Indonesia Nomor 10 Tahun 2009 tentenf Kepariwisataan. Jakarta (ID) : Sekretariat Negara. 